\title{
Nélio Baptista Barros (1960-2010) - A PiONEer At hOME AND ABroAD
}

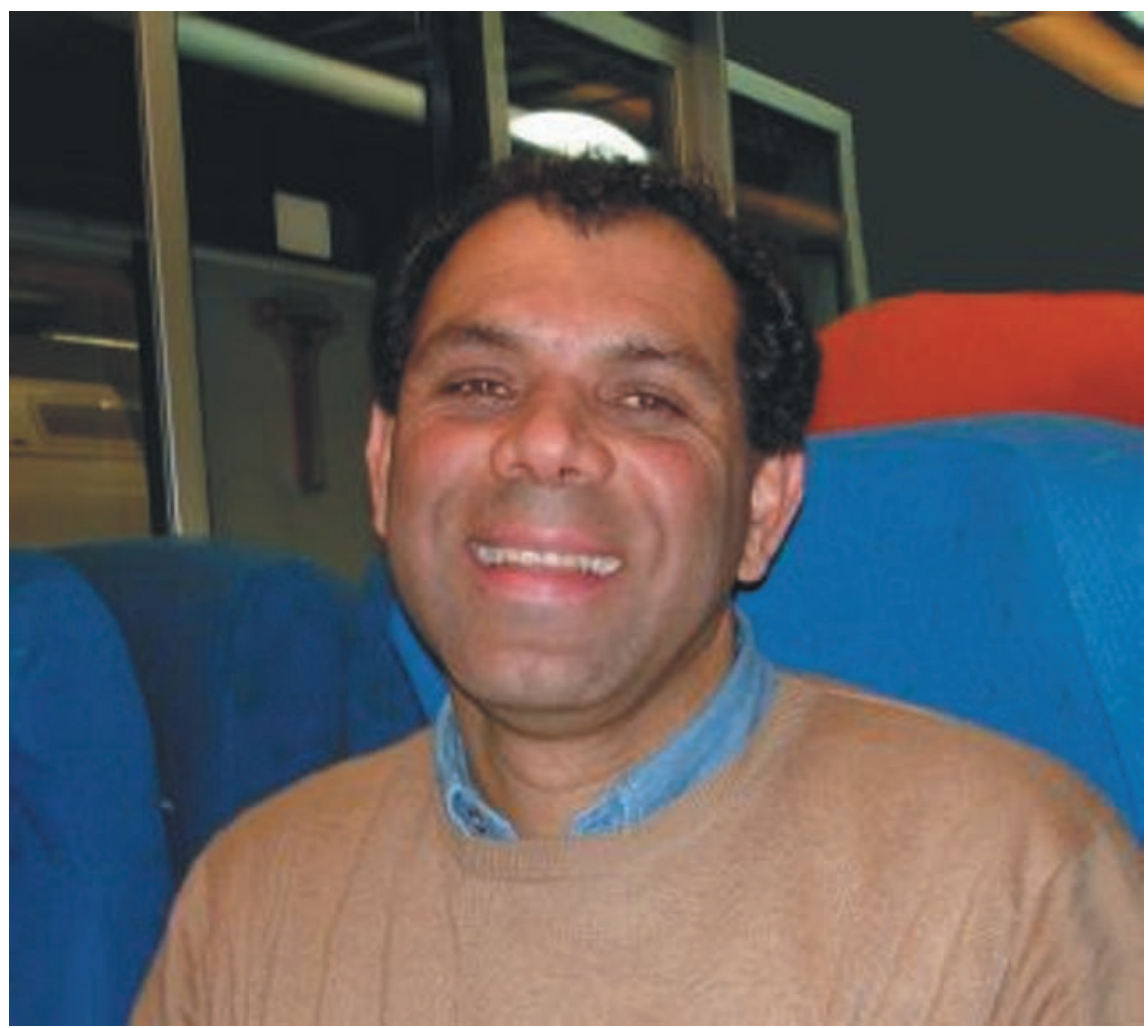

Dr. Nélio Baptista Barros passed away on 10 February 2010 in Tillamook, Oregon, USA, after a battle with cancer. Nélio will be remembered as one of the Latin American pioneers in marine mammal research at a time when only a handful of researchers had begun exploring this vast but unknown field in Brazil.

Nélio was a 'Capixaba,' as natives of the southeastern State of Espírito Santo (ES) are called. He was born in the seashore town of Vila Velha on 23 January 1960, where he lived with his parents, Celeste and Amylton and siblings Geisa and Luiz Rogério. Nélio attended primary and middle school at the Grupo Escolar Vasco Coutinho and Colégio Marista, both in Vila Velha, and Colégio Nacional, in adjacent Vitória, ES. He then attended high school at Colégio Salesiano, also in Vitória.

His call to embrace marine mammal research as a career choice came after a couple of years in engineering school. With much enthusiasm he transferred to the Oceanography Department at the Universidade Federal do Rio Grande (FURG), in southern Brazil, where he received his B.Sc. in Biological Oceanography in 1982. At that time, FURG was one of the only two Brazilian institutions to conduct marine mammal research.

During his undergraduate years, the traits and personality that so distinguished Nélio throughout his career could already be perceived by his peers and the many who, like Nélio, struggled to cope with the dayto-day hurdles of conducting research in developing nations. He was caring, resourceful, creative and always ready to help. Many researchers leading marine mammal work in Latin America today will certainly identify with these early years.

His love for traveling and languages brought him at an early age to Pottsville High School in Pottsville, Arkansas, USA, for an exchange program. From there on Nélio conquered, through his dedication, thoroughness and tremendous stamina, the muchcoveted opportunity to continue his studies abroad. He attended the Rosenstiel School of Marine and Atmospheric Science (RSMAS) at the University of Miami, Florida, USA, where he received his M.Sc. in Biological Oceanography in July 1987, followed by his Ph.D. also from RSMAS in 1993, both under Dr. Dan Odell. During these years Nélio was always ready to assist students and young researchers throughout Latin America with various needs. He would often receive endless requests for literature reprints (before the age of the Internet) or for purchases of research equipment, and he would often be asked to perform identifications of stomach contents and to review translations of manuscripts to English. His constant encouragement, words of wisdom and genuine friendship were appreciated by many and have no doubt been instrumental in consolidating and shaping a new generation of marine mammal researchers, especially in Brazil.

Upon completing his graduate work, Nélio could be considered a true oceanographer with a specialty in 
marine biology - specifically marine mammal feeding ecology. After his Ph.D. his professional career started at Hubbs-SeaWorld Research Institute in Orlando, Florida. He worked there as a marine mammal consultant beginning in 1991, and then as a Research Biologist and Senior Research Biologist during 19942000. He then joined Mote Marine Laboratory in Sarasota, Florida, as a Senior Scientist, where he served as Program Manager for Mote's Stranding Investigations Program during 2000-2006, creating a model stranding response program for the southeastern USA, and developing a laboratory for cetacean stomach content analyses. The collaborations he began while investigating stomach contents and feeding patterns of long-term resident Sarasota Bay bottlenose dolphins with the Chicago Zoological Society's Sarasota Dolphin Research Program (also based at Mote) in the mid-1990s continued until the time of his death, leading to important new insights into bottlenose dolphin ecology and behavior.

Although living for over 20 years in Florida, Nélio always preferred colder climates. It was with much joy in 2006 that he looked forward to his new position at Portland State University, in the cooler, if wetter, Oregon climate. He joined PSU's Department of Biology to pursue feeding ecology research in the Pacific Northwest and to help coordinate the Northern Oregon/Southern Washington Marine Mammal Stranding Program. With his expertise in the feeding ecology of small and large cetaceans, he continued using stomach contents and tissue samples to examine prey and stable isotope concentrations with the goal of determining trophic interactions. Another dimension of Nélio's research involved identifying the importance of sound-producing fish in the diet of bottlenose dolphins, dispelling the long-held notion that bottlenose dolphins are opportunistic feeders, when in fact they select soniferous fish prey. He filled many gaps in our knowledge of the biology and ecology of difficult-tostudy pygmy and dwarf sperm whales. In the USA, wildlife management and government agencies called upon him for information on feeding habits of pinnipeds and cetaceans derived from strandings and Unusual Mortality Events.

Outside the USA and Brazil, he contributed to field research in Hong Kong and South Africa and participated in many conferences and international workshops. But it was in the USA that Nélio flourished as a researcher and where he found his life partner, Fred Casey, who survives him along with parents and siblings in Brazil. Together they explored many parts of the world and Nélio used these as opportunities to practice his skills in languages. Besides his native Portuguese, he was fluent in English, Spanish and French and studied Russian for several years. He and Fred loved cooking and experiencing recipes from all over the world. Nélio often surprised colleagues and friends with warm chocolate chip cookies hot from the oven. After moving to Oregon, he enjoyed having the ample space in his dream home in Tillamook to garden and to harvest eggs from his flock of free-range chickens ('his girls'). He also had other interests, such as aviation and tennis.

Nélio authored or co-authored 34 peer-reviewed papers or book chapters. His constructive reviews of manuscripts and keen eye for editing earned him a challenging and demanding role at the Latin American Journal of Aquatic Mammals, first as co-Editor-in-Chief (2005-2008) and then as Editor-in-Chief (2008-2009). In typical Nélio style he stepped up to the task with distinction. And it was no surprise then when he gladly accepted the offer to serve in the organizing committee in charge of convening the 'Workshop on Research and Conservation of the genus Sotalia' that is the subject of this Special Volume, helping in every way and actively participating to make it a reality. The community of Latin American researchers, through LAJAM, has the honour to dedicate this Special Volume to his loving memory, with deepest sorrow for his early departure.

Let us always remember Nélio - or as Brazilians would say, as they practically never address one another by last names - Dr. Nélio, with warm, fond memories of his free spirit and above all for his contributions to marine mammal research, particularly feeding ecology. He will be forever missed and remembered.

\section{Monica Borobia ${ }^{1,2,}$, Daniel M. Palacios ${ }^{3,4}$, Randall S. Wells ${ }^{5}$, Megan K. Stolen $^{6}$, and Eduardo R. Secchi ${ }^{7}$}

\footnotetext{
${ }^{1}$ Fernando J. da Silva, 42, Rio de Janeiro RJ 22723-310 Brazil

${ }^{2}$ Present address: 5-46484 Chilliwack Lake Road, Chilliwack, British Columbia, V2R 3R7 Canada

* Corresponding author, e-mail: m_borobia@yahoo.com

${ }^{3}$ Joint Institute for Marine and Atmospheric Research, University of Hawaii, 1000 Pope Road, Marine Sciences Building, Room 312, Honolulu, HI 96822, USA

${ }^{4}$ NOAA/NMFS/SWFSC, Environmental Research Division, 1352 Lighthouse Avenue, Pacific Grove, CA 93950, USA

${ }^{5}$ Sarasota Dolphin Research Program, Chicago Zoological Society, c/o Mote Marine Laboratory, 1600 Ken Thompson Parkway, Sarasota, FL 34236, USA

${ }^{6}$ Hubbs-SeaWorld Research Institute, 6295 Sea Harbor Drive, Orlando, FL 32821-8043, USA

${ }^{7}$ Laboratório de Tartarugas e Mamíferos Marinhos, Instituto de Oceanografia, Universidade Federal do Rio Grande, Rio Grande, RS, Brazil
} 